\title{
Synthesis of progesterone heterocyclic derivatives of potential antimicrobial activity
}

\author{
RAFAT M. MOHAREB ${ }^{1 *}$ \\ HANAA Y. HANA ${ }^{2}$ \\ ${ }^{1}$ Department of Organic Chemistry \\ Faculty of Pharmacy, University of \\ Modern Sciences and Arts (MSA) \\ October City, Giza, Egypt \\ ${ }^{2}$ Hormone Department, National \\ Research Centre, Dokki, Giza, Egypt
}

Accepted February 5, 2008

\begin{abstract}
The aim of this work was to synthesize steroidal heterocycles and to elucidate the potential role of these compounds as antimicrobial agents. The synthesis of steroidal heterocycles containing the pyrazole, isoxazole, thiazole, pyrane, pyridine, pyridazine, or benzopyrane ring attached to the pregnene nucleus is reported. Progesterone (1) reacts with dimethyl formamide dimethyl acetal to form enamine $\mathbf{2}$. Heterocyclization of $\mathbf{2}$ with hydrazines, hydroxylamine, glycine, ethyl acetoacetate or cyanomethylene afforded novel steroidal heterocyclic derivatives. The in vitro antimicrobial evaluation showed that all synthesized compounds show activity against the used strains of Gram positive bacteria and fungi.
\end{abstract}

Keywords: progesterone, enamine, pyrazole, pyrane, antimicrobial

Progesterone is one of the most important hormones of the steroidal pregnane series, secreted by corpus luteum and by placenta, which can be regarded as a hormonal balancer, particularly of estrogens. It also helps to create a balance of all other steroids and has intrinsic calming and diuretic properties. It is important in women and its importance in men for the maintenance of prostate health is appreciated. Moreover, progesterone has a neuroprotective effect $(1,2)$. Thus, due to the importance of progesterones to the human body and in continuation of our previous work on heterocyclic synthesis (3-5), we would like to report here on the formation and characterization of new promising steroidal heterocyclic derivatives derived from progesterone. Detection of many emerging chemicals of concern, including antimicrobials and steroid hormones, in the environment was increased in the past decade with the advancement of analytical techniques. All compounds produced in this work are novel and their synthetic pathways are also novel. Therefore, the in vitro antimicrobial activity of the new steroidal derivatives should be tested against Gram positive and negative bacteria, and fungi.

\footnotetext{
* Correspondence, e-mail: raafat-mohareb@yahoo.com
} 
R. M. Mohareb and H. Y. Hana: Synthesis of progesterone heterocyclic derivatives of potential antimicrobial activity, Acta Pharm. 58 (2008) $29-42$

\section{EXPERIMENTAL}

\section{Synthetic methods, analytical and spectral data}

Starting steroids were purchased from Sigma Company (Germany). Appropriate precautions in handling moisture sensitive compounds were undertaken. Melting points were determined on an electrothermal apparatus (Büchi 535, Switzerland) in an open capillary tube and are uncorrected. Elemental analyses were performed on a Yanaco CHN Corder elemental analyzer (Japan). IR spectra $\left(v, \mathrm{~cm}^{-1}\right)$ were recorded in $\mathrm{KBr}$ pellets on a PA-9721 IR spectrophotometer (Shimadzu, Japan). ${ }^{1} \mathrm{H}$ NMR spectra were obtained on a Jeol $300 \mathrm{MHz}$ (Japan) spectrometer in DMSO-d $\mathrm{d}_{6}$ as solvent, using TMS as internal reference and chemical shifts $(\delta)$ are expressed in ppm. Mass spectra were recorded on Kratos $(75 \mathrm{eV}) \mathrm{MS}$ equipment (Germany).

For the nomenclature of steroid derivatives, we used the definitive rules for the nomenclature of steroid published by the Joint Commission on the Biochemical Nomenclature $(\mathrm{JCBN})$ of IUPAC $(6,7)$.

Compound 2 was synthesized by reacting progesterone with dimethylformamide dimethylacetal in refluxing xylene solution according to the literature procedure (8). Synthetic pathways are presented in Schemes 1, 2, 3 and 4, and physicochemical and spectral data for the synthesized compounds are given in Tables I and II.

Synthesis of 17-(pyrazol-3-yl)androst-4-en-3-one (3a) and 17-(1-phenylpyrazol-3-yl)androst-4-en-3-one (3b)

General procedure. - To a solution of compound $2(0.66 \mathrm{~g}, 0.002 \mathrm{~mol})$ in absolute ethanol $(30 \mathrm{~mL})$, either hydrazine hydrate $(0.1 \mathrm{~g}, 0.002 \mathrm{~mol})$ or phenylhydrazine $(0.2 \mathrm{~g}, 0.002$ mol) was added. The reaction mixture, in each case, was heated under reflux for $5 \mathrm{~h}$, then left to cool at room temperature and poured into ice/water mixture. The formed solid product collected by filtration was dried and crystallized to give either 3a (crystallized from ethanol) or $\mathbf{3 b}$ (crystallized from 1,4-dioxane).

Synthesis of 17-(isoxazol-6-yl)androst-4-en-3-one (4)

To a solution of compound $2(0.66 \mathrm{~g}, 0.002 \mathrm{~mol})$ in absolute ethanol $(30 \mathrm{~mL})$, containing sodium acetate $(0.16 \mathrm{~g}, 0.002 \mathrm{~mol})$, an equivalent amount of hydroxylamine hydrochloride $(0.13 \mathrm{~g}, 0.002 \mathrm{~mol})$ in water $(5 \mathrm{~mL})$ was added. The reaction mixture was boiled under reflux for $3 \mathrm{~h}$ then left to cool to $20^{\circ} \mathrm{C}$ and poured over ice/water mixture. The formed solid product was collected by filtration and crystallized from 1,4-dioxane.

Synthesis of 17-(2-amino-3-cyanopyran-6-yl)androst-4-en-3-one (6a)

Malononitrile $(0.13 \mathrm{~g}, 0.002 \mathrm{~mol})$ was added to a suspension of compound 2 (0.66, $0.002 \mathrm{~mol})$ in sodium ethoxide $(0.01 \mathrm{~mol})$ [prepared by dissolving sodium metal $(0.23 \mathrm{~g}$, $0.01 \mathrm{~mol})$ in absolute ethanol $(5 \mathrm{~mL})]$. The reaction mixture was heated under reflux for $5 \mathrm{~h}$, then left to cool at room temperature, poured into ice/water mixture and neutralized with dilute hydrochloric acid. The solid product $\mathbf{6 a}$, which was formed through the formation of the non isolable intermediate $\mathbf{5 a}$, was collected by filtration, dried and crystallized from ethanol. 
R. M. Mohareb and H. Y. Hana: Synthesis of progesterone heterocyclic derivatives of potential antimicrobial activity, Acta Pharm. 58 (2008) 29-42.

Table I. Physico-chemical data for synthesized compounds

\begin{tabular}{|c|c|c|c|c|c|c|c|}
\hline \multirow{2}{*}{$\begin{array}{l}\text { Compd. } \\
\text { No. }\end{array}$} & \multirow{2}{*}{$\begin{array}{l}\text { Yield } \\
(\%)\end{array}$} & \multirow{2}{*}{$\begin{array}{l}\text { M.p. } \\
\left({ }^{\circ} \mathrm{C}\right)\end{array}$} & \multirow{2}{*}{$\begin{array}{l}\text { Mol. formula } \\
\qquad\left(M_{\mathrm{r}}\right)\end{array}$} & \multicolumn{4}{|c|}{ Found/calcd. (\%) } \\
\hline & & & & $\mathrm{C}$ & $\mathrm{H}$ & $\mathrm{N}$ & S \\
\hline \multirow{2}{*}{$3 a$} & \multirow{2}{*}{75} & \multirow{2}{*}{ 100-102 } & $\mathrm{C}_{22} \mathrm{H}_{30} \mathrm{~N}_{2} \mathrm{O}$ & 77.32 & 8.74 & 8.12 & - \\
\hline & & & (338.49) & 77.06 & 8.93 & 8.27 & - \\
\hline \multirow{2}{*}{$3 b$} & \multirow{2}{*}{69} & \multirow{2}{*}{ 97-99 } & $\mathrm{C}_{28} \mathrm{H}_{34} \mathrm{~N}_{2} \mathrm{O}$ & 80.94 & 8.13 & 6.55 & - \\
\hline & & & $(414.59)$ & 81.11 & 8.26 & 6.75 & - \\
\hline \multirow{2}{*}{4} & \multirow{2}{*}{74} & \multirow{2}{*}{$165-167$} & $\mathrm{C}_{22} \mathrm{H}_{29} \mathrm{NO}_{2}$ & 77.67 & 8.33 & 4.03 & - \\
\hline & & & $(339.48)$ & 77.83 & 8.61 & 4.12 & - \\
\hline \multirow{2}{*}{$6 a$} & \multirow{2}{*}{69} & \multirow{2}{*}{$152-155$} & $\mathrm{C}_{25} \mathrm{H}_{32} \mathrm{~N}_{2} \mathrm{O}_{2}$ & 74.33 & 8.11 & 7.08 & - \\
\hline & & & (392.54) & 74.49 & 8.21 & 7.13 & - \\
\hline \multirow{2}{*}{$6 b$} & \multirow{2}{*}{68} & \multirow{2}{*}{ 100-101 } & $\mathrm{C}_{25} \mathrm{H}_{31} \mathrm{NO}_{3}$ & 76.22 & 7.75 & 3.32 & - \\
\hline & & & $(393.53)$ & 76.30 & 7.94 & 3.55 & - \\
\hline \multirow{2}{*}{7} & \multirow{2}{*}{72} & \multirow{2}{*}{$118-120$} & $\mathrm{C}_{30} \mathrm{H}_{43} \mathrm{NO}_{4}$ & 74.71 & 8.65 & 2.82 & - \\
\hline & & & $(481.68)$ & 74.80 & 8.99 & 2.90 & - \\
\hline \multirow{2}{*}{9} & \multirow{2}{*}{76} & \multirow{2}{*}{$178-179$} & $\mathrm{C}_{26} \mathrm{H}_{33} \mathrm{O}_{4}$ & 76.00 & 8.31 & - & - \\
\hline & & & $(410.55)$ & 76.06 & 8.34 & - & - \\
\hline \multirow{2}{*}{11} & \multirow{2}{*}{78} & \multirow{2}{*}{$109-110$} & $\mathrm{C}_{25} \mathrm{H}_{31} \mathrm{ON}_{3}$ & 77.00 & 7.98 & 10.56 & - \\
\hline & & & (389.54) & 77.08 & 8.02 & 10.78 & - \\
\hline 13 & 68 & $188-189$ & $\mathrm{C}_{23} \mathrm{H}_{31} \mathrm{NO}$ & 81.64 & 9.12 & 4.01 & - \\
\hline 13 & 68 & $188-189$ & $(337.51)$ & 81.85 & 9.25 & 4.15 & - \\
\hline 14 & 68 & $188 \quad 190$ & $\mathrm{C}_{24} \mathrm{H}_{33} \mathrm{~N}_{3} \mathrm{O}_{2}$ & 72.62 & 8.25 & 10.53 & - \\
\hline 14 & 00 & $100-190$ & (395.55) & 72.87 & 8.40 & 10.62 & - \\
\hline 15 & 77 & 70 & $\mathrm{C}_{31} \mathrm{H}_{37} \mathrm{~N}_{3} \mathrm{O}_{2}$ & 76.76 & 7.58 & 8.54 & - \\
\hline 15 & 17 & $70-72$ & $(483.65)$ & 76.98 & 7.71 & 8.68 & - \\
\hline & & & $\mathrm{C}_{27} \mathrm{H}_{34} \mathrm{~N}_{4} \mathrm{O}_{3}$ & 69.82 & 7.12 & 12.31 & - \\
\hline 17 & 66 & $210-212$ & (462.59) & 70.10 & 7.40 & 12.11 & - \\
\hline & & & (462) & & & & \\
\hline 18 & 70 & $210-212$ & $\mathrm{C}_{28} \mathrm{H}_{38} \mathrm{~N}_{2} \mathrm{O}_{2}$ & 77.52 & 8.63 & 6.24 & - \\
\hline & & & $(434.62)$ & 77.37 & 8.81 & 6.44 & - \\
\hline 19 & 75 & $167-168$ & $\mathrm{C}_{26} \mathrm{H}_{35} \mathrm{~N}_{3} \mathrm{O}_{3} \mathrm{~S}$ & 69.67 & 7.35 & 8.74 & 6.82 \\
\hline & & & $(469.65)$ & 69.94 & 7.51 & 8.94 & 6.82 \\
\hline 20 & 75 & $84-86$ & $\mathrm{C}_{31} \mathrm{H}_{36} \mathrm{~N}_{2} \mathrm{O}_{4}$ & 74.17 & 7.04 & 5.39 & - \\
\hline & & & $(500.64)$ & 74.37 & 7.24 & 5.59 & - \\
\hline
\end{tabular}

Synthesis of 17-(2-hydroxy-3-cyanopyran-6-yl)androst-4-en-3-one (6b)

To a solution of compound $2(0.66,0.002 \mathrm{~mol})$ in ethanol $(30 \mathrm{~mL})$, containing a catalytic amount of triethylamine $(0.5 \mathrm{~mL})$, an equivalent amount of ethyl cyanoacetate $(0.23 \mathrm{~g}$, $0.002 \mathrm{~mol}$ ) was added. The reaction mixture was heated under reflux for $5 \mathrm{~h}$; after cooling at room temperature, it was poured into ice/water mixture and neutralized with di- 
R. M. Mohareb and H. Y. Hana: Synthesis of progesterone heterocyclic derivatives of potential antimicrobial activity, Acta Pharm. 58 (2008) 29-42.

Table II. Spectral data of newly synthesized products

\begin{tabular}{|c|c|c|c|}
\hline $\begin{array}{c}\text { Compd. } \\
\text { No. }\end{array}$ & $\operatorname{IR}\left(v, \mathrm{~cm}^{-1}\right)$ & ${ }^{1} \mathrm{H}$ NMR $(\delta, \mathrm{ppm})\left(\mathrm{DMSO}^{\left.-\mathrm{d}_{6}\right)}\right.$ & MS $\left(\mathrm{M}^{+}\right)$ \\
\hline $3 a$ & $\begin{array}{l}3300(\mathrm{NH}), 2980,2860 \\
\left(\mathrm{CH}_{3}, \mathrm{CH}_{2}\right), 1715(\mathrm{C}=\mathrm{O}) \\
1659(\mathrm{C}=\mathrm{N}), 1576(\mathrm{C}=\mathrm{C})\end{array}$ & $\begin{array}{l}0.75\left(\mathrm{~s}, 3 \mathrm{H}, 18-\mathrm{CH}_{3}\right), 0.92\left(\mathrm{~s}, 3 \mathrm{H}, 19-\mathrm{CH}_{3}\right) \\
4.97(\mathrm{~s}, 1 \mathrm{H}, \mathrm{C} 4-\mathrm{H}), 6.14(\mathrm{~d}, 1 \mathrm{H}, \text { pyrazole, } \\
\mathrm{H}-4), 6.22(\mathrm{~d}, 1 \mathrm{H}, \text { pyrazole, H-5), } 9.11(\mathrm{~s}, \\
\left.1 \mathrm{H}, \mathrm{NH}, \mathrm{D}_{2} \mathrm{O}-\text {-exchangeable }\right)\end{array}$ & 338 \\
\hline $3 b$ & $\begin{array}{l}3050(\mathrm{CH} \text {-aromatic }), 2980, \\
2863\left(\mathrm{CH}_{3}, \mathrm{CH}_{2}\right), 1715 \\
(\mathrm{C}=\mathrm{O}), 1650(\mathrm{C}=\mathrm{N}), 1590 \\
(\mathrm{C}=\mathrm{C})\end{array}$ & $\begin{array}{l}0.75\left(\mathrm{~s}, 3 \mathrm{H}, 18-\mathrm{CH}_{3}\right), 0.92\left(\mathrm{~s}, 3 \mathrm{H}, 19-\mathrm{CH}_{3}\right) \\
4.82(\mathrm{~s}, 1 \mathrm{H}, \mathrm{C} 4-\mathrm{H}), 6.19(\mathrm{~d}, 1 \mathrm{H}, \text { pyrazole, } \\
\mathrm{H}-4), 6.34(\mathrm{~d}, 1 \mathrm{H}, \text { pyrazole H-5), } 7.31-7.56 \\
\left(\mathrm{m}, 5 \mathrm{H}, \mathrm{C}_{6} \mathrm{H}_{5}\right)\end{array}$ & 414 \\
\hline 4 & $\begin{array}{l}\text { 2987, } 2855\left(\mathrm{CH}_{3}, \mathrm{CH}_{2}\right) \\
1718(\mathrm{C}=\mathrm{O}), 1650(\mathrm{C}=\mathrm{N}) \\
1580(\mathrm{C}=\mathrm{C})\end{array}$ & $\begin{array}{l}0.72\left(\mathrm{~s}, 3 \mathrm{H}, 18-\mathrm{CH}_{3}\right), 0.89\left(\mathrm{~s}, 3 \mathrm{H}, 19-\mathrm{CH}_{3}\right) \\
4.70(\mathrm{~s}, 1 \mathrm{H}, \mathrm{C} 4-\mathrm{H}), 4.83(\mathrm{~d}, 1 \mathrm{H}, \text { isoxazole, } \\
\mathrm{H}-4), 5.23(\mathrm{~d}, 1 \mathrm{H} \text {, isoxazole, H-5) }\end{array}$ & 339 \\
\hline $6 a$ & $\begin{array}{l}3320\left(\mathrm{NH}_{2}\right), 2980,2860 \\
\left(\mathrm{CH}_{3}, \mathrm{CH}_{2}\right), 2225,(\mathrm{CN}) \\
1710(\mathrm{C}=\mathrm{O}), 1580(\mathrm{C}=\mathrm{C})\end{array}$ & $\begin{array}{l}0.88\left(\mathrm{~s}, 3 \mathrm{H}, 18-\mathrm{CH}_{3}\right), 1.05\left(\mathrm{~s}, 3 \mathrm{H}, 19-\mathrm{CH}_{3}\right) \\
4.72(\mathrm{~s}, 1 \mathrm{H}, \mathrm{C} 4-\mathrm{H}), 6.33\left(\mathrm{~s}, 1 \mathrm{H}, \mathrm{NH}_{2}, \mathrm{D}_{2} \mathrm{O}\right. \\
\text { exchangeable), } 7.03(\mathrm{~d}, 1 \mathrm{H}, \text { pyrane, } \mathrm{H}-4) \\
7.12(\mathrm{~d}, 1 \mathrm{H}, \text { pyrane, } \mathrm{H}-5)\end{array}$ & 392 \\
\hline $6 b$ & $\begin{array}{l}3400(\mathrm{OH}), 2982,2820 \\
\left(\mathrm{CH}_{3}, \mathrm{CH}_{2}\right), 1715(\mathrm{C}=\mathrm{O}) \\
1590(\mathrm{C}=\mathrm{C})\end{array}$ & $\begin{array}{l}0.83\left(\mathrm{~s}, 3 \mathrm{H}, 18-\mathrm{CH}_{3}\right), 1.07\left(\mathrm{~s}, 3 \mathrm{H}, 19-\mathrm{CH}_{3}\right) \\
4.76(\mathrm{~s}, 1 \mathrm{H}, \mathrm{C} 4-\mathrm{H}), 7.03(\mathrm{~d}, 1 \mathrm{H}, \text { pyrane, } \\
\mathrm{H}-4), 7.12(\mathrm{~d}, 1 \mathrm{H}, \text { pyrane, } \mathrm{H}-5), 9.57(\mathrm{~s}, \\
\left.1 \mathrm{H}, \mathrm{OH}, \mathrm{D}_{2} \mathrm{O} \text { exchangeable }\right)\end{array}$ & 393 \\
\hline 7 & $\begin{array}{l}\text { 2980, } 2863\left(\mathrm{CH}_{3}, \mathrm{CH}_{2}\right) \\
1735,1722,1710(3 \mathrm{C}=\mathrm{O}) \\
1590(\mathrm{C}=\mathrm{C})\end{array}$ & $\begin{array}{l}0.83\left(\mathrm{~s}, 3 \mathrm{H}, 18-\mathrm{CH}_{3}\right), 1.03\left(\mathrm{~s}, 3 \mathrm{H}, 19-\mathrm{CH}_{3}\right) \\
1.32\left(\mathrm{t}, 3 \mathrm{H}, \text { ester } \mathrm{CH}_{3}\right), 2.34(\mathrm{~s}, 1 \mathrm{H}, \\
\left.\mathrm{COCH}_{3}\right), 4.22\left(\mathrm{q}, 2 \mathrm{H}, \text { ester } \mathrm{CH}_{2}\right), 4.82(\mathrm{~s}, \\
1 \mathrm{H}, \mathrm{C} 4-\mathrm{H}), 4.95(\mathrm{~d}, 1 \mathrm{H}, \mathrm{CH}), 5.23(\mathrm{~d}, 1 \mathrm{H}, \\
\mathrm{CH}) .4 .95(\mathrm{~d}, 1 \mathrm{H}, \mathrm{CH}), 5.23(\mathrm{~d}, 1 \mathrm{H}, \mathrm{CH})\end{array}$ & 481 \\
\hline 9 & $\begin{array}{l}3300(\mathrm{OH}), 2980,2863 \\
\left(\mathrm{CH}_{3}, \mathrm{CH}_{2}\right), 1725,1708 \\
(2 \mathrm{C}=\mathrm{O}), 1590(\mathrm{C}=\mathrm{C})\end{array}$ & $\begin{array}{l}0.79\left(\mathrm{~s}, 3 \mathrm{H}, 18-\mathrm{CH}_{3}\right), 0.95\left(\mathrm{~s}, 3 \mathrm{H}, 19-\mathrm{CH}_{3}\right) \\
2.23(\mathrm{~s}, 3 \mathrm{H}, \mathrm{COCH}), 6.91(\mathrm{~d}, 1 \mathrm{H}, \text { pyran, } \\
\mathrm{H}-4), 7.02(\mathrm{~d}, 1 \mathrm{H}, \text { pyran, } \mathrm{H}-5), 9.57(\mathrm{~s}, 1 \mathrm{H}, \\
\left.\mathrm{OH}, \mathrm{D}_{2} \mathrm{O}-\text { exchangeable }\right)\end{array}$ & 410 \\
\hline 11 & $\begin{array}{l}\text { 2980, } 2860\left(\mathrm{CH}_{3}, \mathrm{CH}_{2}\right) \\
2225(\mathrm{CN}), 1710(\mathrm{C}=\mathrm{O}) \\
1580(\mathrm{C}=\mathrm{C})\end{array}$ & $\begin{array}{l}0.78\left(\mathrm{~s}, 3 \mathrm{H}, 18-\mathrm{CH}_{3}\right), 0.95\left(\mathrm{~s}, 3 \mathrm{H}, 19-\mathrm{CH}_{3}\right) \\
4.70(\mathrm{~s}, 1 \mathrm{H}, \mathrm{C} 4-\mathrm{H}), 1.25,1.32(2 \mathrm{~s}, 6 \mathrm{H}, 2 \\
\left.\mathrm{CH}_{3}\right), 2.11\left(\mathrm{~s}, 1 \mathrm{H}, \mathrm{CH}_{2}\right), 5.93(\mathrm{~d}, 1 \mathrm{H}, \text { pyra- } \\
\text { dizine, } \mathrm{CH}), 6.03(\mathrm{~d}, 1 \mathrm{H}, \text { pyradizine, } \mathrm{CH})\end{array}$ & 389 \\
\hline 13 & $\begin{array}{l}3334(\mathrm{NH}), 2980,2860 \\
\left(\mathrm{CH}_{3}, \mathrm{CH}_{2}\right), 1715(\mathrm{C}=\mathrm{O}) \\
1576(\mathrm{C}=\mathrm{C})\end{array}$ & $\begin{array}{l}0.75\left(\mathrm{~s}, 3 \mathrm{H}, 18-\mathrm{CH}_{3}\right), 0.92\left(\mathrm{~s}, 3 \mathrm{H}, 19-\mathrm{CH}_{3}\right) \\
4.97(\mathrm{~s}, 1 \mathrm{H}, \mathrm{C} 4-\mathrm{H}), 5.23(\mathrm{~m}, 2 \mathrm{H}, \text { pyrol, } \\
\mathrm{H}-2, \mathrm{H}-3), 8.14(\mathrm{~s}, 1 \mathrm{H}, \text { pyrol, CH), } 9.11(\mathrm{~s}, \\
\left.1 \mathrm{H}, \mathrm{NH}, \mathrm{D}_{2} \mathrm{O}-\text { exchangeable }\right)\end{array}$ & 337 \\
\hline 14 & $\begin{array}{l}3360(\mathrm{NH}), 2980,2855 \\
\left(\mathrm{CH}_{3}, \mathrm{CH}_{2}\right), 2225(\mathrm{CN}) \\
1718,1715(2 \mathrm{C}=\mathrm{O}), 1630 \\
(\mathrm{C}=\mathrm{N}), 1580(\mathrm{C}=\mathrm{C})\end{array}$ & $\begin{array}{l}0.78\left(\mathrm{~s}, 3 \mathrm{H}, 18-\mathrm{CH}_{3}\right), 0.95\left(\mathrm{~s}, 3 \mathrm{H}, 19-\mathrm{CH}_{3}\right) \\
1.15\left(\mathrm{~s}, 3 \mathrm{H}, 21-\mathrm{CH}_{3}\right), 2.11\left(\mathrm{~s}, 2 \mathrm{H}, \mathrm{CH}_{2}\right) \\
4.83(\mathrm{~s}, 1 \mathrm{H}, \mathrm{C} 4-\mathrm{H}), 9.55\left(\mathrm{~s}, 1 \mathrm{H}, \mathrm{NH}, \mathrm{D}_{2} \mathrm{O}\right. \\
\text { exchangeable })\end{array}$ & 395 \\
\hline
\end{tabular}


R. M. Mohareb and H. Y. Hana: Synthesis of progesterone heterocyclic derivatives of potential antimicrobial activity, Acta Pharm. 58 (2008) 29-42.

$153320(\mathrm{NH}), 3030(\mathrm{CH}-$ aromatic), 2982, $2868\left(\mathrm{CH}_{3}\right.$, $\left.\mathrm{CH}_{2}\right), 2225(\mathrm{CN}), 1730$, $1710(2 \mathrm{C}=\mathrm{O}), 1640(\mathrm{C}=\mathrm{N})$, $1590(\mathrm{C}=\mathrm{C})$

$173435\left(\mathrm{NH}_{2}\right), 2982,2868$ $\left(\mathrm{CH}_{3}, \mathrm{CH}_{2}\right), 2220(\mathrm{CN})$, 1730, 1718, $1710(3 \mathrm{C}=\mathrm{O})$, $1640(\mathrm{C}=\mathrm{N}), 1590(\mathrm{C}=\mathrm{C})$

$182980,2860\left(\mathrm{CH}_{3}, \mathrm{CH}_{2}\right)$, 1725, $1710(2 \mathrm{C}=\mathrm{O}), 1640$ $(\mathrm{C}=\mathrm{N}), 1580(\mathrm{C}=\mathrm{C})$

$193325(\mathrm{NH}), 2980,2860$ $\left(\mathrm{CH}_{3}, \mathrm{CH}_{2}\right), 1718,1710$, $1695(3 \mathrm{C}=\mathrm{O}), 1640(\mathrm{C}=\mathrm{N})$

20 3325 (NH), 3050 (CH aromatic), 2980, $2855 \mathrm{CH}_{3}$, $\left.\mathrm{CH}_{2}\right), 1730,1710,1690$ (3 $\mathrm{C}=\mathrm{O}), 1630(\mathrm{C}=\mathrm{N}), 1578$ $(\mathrm{C}=\mathrm{C})$ $0.75\left(\mathrm{~s}, 3 \mathrm{H}, 18-\mathrm{CH}_{3}\right), 0.97\left(\mathrm{~s}, 3 \mathrm{H}, 19-\mathrm{CH}_{3}\right)$, $1.10\left(\mathrm{~s}, 3 \mathrm{H}, 21-\mathrm{CH}_{3}\right), 4.73(\mathrm{~s}, 1 \mathrm{H}, \mathrm{C} 4-\mathrm{H}), 5$ $\left.\mathrm{H}, \mathrm{C}_{6} \mathrm{H}_{5}\right), 8.51$ (s, $1 \mathrm{H}, \mathrm{NH}, \mathrm{D}_{2} \mathrm{O}$ exchangeable)

$0.75\left(\mathrm{~s}, 3 \mathrm{H}, 18-\mathrm{CH}_{3}\right), 0.97\left(\mathrm{~s}, 3 \mathrm{H}, 19-\mathrm{CH}_{3}\right)$, $1.10\left(\mathrm{~s}, 3 \mathrm{H}, 21-\mathrm{CH}_{3}\right), 4.31$ (s, 2H, pyridine, $\mathrm{H}-5), 4.91$ (s, 1H, C4-H), 6.33 (s, 2H, $\mathrm{NH}_{2}$, $\mathrm{D}_{2} \mathrm{O}$ exchangeable)

0.78 (s, 3H, 18- $\left.\mathrm{CH}_{3}\right), 0.95\left(\mathrm{~s}, 3 \mathrm{H}, 19-\mathrm{CH}_{3}\right)$, $1.05\left(\mathrm{~s}, 3 \mathrm{H}, 21-\mathrm{CH}_{3}\right), 1.21,1.34(2 \mathrm{~s}, 6 \mathrm{H}$, $\left.2 \mathrm{CH}_{3}\right), 4.70(\mathrm{~s}, 1 \mathrm{H}, \mathrm{C} 4-\mathrm{H}), 6.28,6.43(2 \mathrm{~s}$, $2 \mathrm{H}$, pyridine, $\mathrm{H}-3$, pyridine $\mathrm{H}-5)$

$0.78\left(\mathrm{~s}, 3 \mathrm{H}, 18-\mathrm{CH}_{3}\right), 0.95\left(\mathrm{~s}, 3 \mathrm{H}, 19-\mathrm{CH}_{3}\right)$, $4.93\left(\mathrm{~s}, 2 \mathrm{H}, \mathrm{CH}_{2}\right), 5.72(\mathrm{~s}, 2 \mathrm{H}$, thiazole, $\mathrm{H}-5), 8.25$ (s, 1H, NH, $\mathrm{D}_{2} \mathrm{O}$ exchangeable)

$0.78\left(\mathrm{~s}, 3 \mathrm{H}, 18-\mathrm{CH}_{3}\right), 0.95\left(\mathrm{~s}, 3 \mathrm{H}, 19-\mathrm{CH}_{3}\right)$, $1.05\left(\mathrm{~s}, 3 \mathrm{H}, 21-\mathrm{CH}_{3}\right), 4.67$ (s, 1H, C4-H), 6.99 (s, 1H, coumarin H-4), 7.32-7.55 (m, 4 $\left.\mathrm{H}, \mathrm{C}_{6} \mathrm{H}_{4}\right), 11.2\left(\mathrm{~s}, 1 \mathrm{H}, \mathrm{NH}, \mathrm{D}_{2} \mathrm{O}\right.$ exchangeable)
483

lute hydrochloric acid. The formed solid product of $\mathbf{6 b}$, which was formed through the intermediate formation of the non isolable $5 \mathbf{b}$, was filtered off, dried, and crystallized from ethanol.

Synthesis of 21-(dimethylaminoacryloyl)-20-(ethylacetoacetato)pregn-4-en-3-one (7)

To a solution of compound $2(0.66 \mathrm{~g}, 0.002 \mathrm{~mol})$ in ethanol containing a catalytic amount of ammonium acetate $(0.1 \mathrm{~g})$, an equivalent amount of ethyl acetoacetate $(0.23 \mathrm{~g}$, $0.002 \mathrm{~mol}$ ) was added. The reaction mixture was heated under reflux for $4 \mathrm{~h}$, then left to cool at room temperature and poured into ice/water mixture. The formed solid product was filtered off, dried and crystallized from 1,4-dioxane.

Synthesis of 17-(2-hydroxy-3-acetylpyran-6-yl)androst-4-en-3-one (9)

To a solution of $2(0.66 \mathrm{~g}, 0.002 \mathrm{~mol})$ in toluene $(30 \mathrm{~mL})$, ethyl acetoacetate $(0.23 \mathrm{~g}$, $0.002 \mathrm{~mol}$ ) was added. The reaction mixture was heated under reflux for $5 \mathrm{~h}$ and then the reaction mixture was concentrated under vacuum. The solid product $\mathbf{9}$, was formed through the intermediate formation of the non isolable 8; it was dried and crystallized from 1,4-dioxane.

Synthesis of 17-(3-cyanomethylpyridazin-6-yl)androst-4-en-3-one (11)

To a solution of compound 2 (0.66 g, $0.002 \mathrm{~mol})$ in 1,4-dioxane $(30 \mathrm{~mL})$, an equivalent amount of freshly prepared cyanoacetic acid hydrazide $(0.19 \mathrm{~g}, 0.002 \mathrm{~mol})$ [prepared by the addition of an equivalent amount of hydrazine hydrate to ethyl cyanoacetate under stirring at room temperature] was added; the reaction mixture was heated under reflux for $6 \mathrm{~h}$ and then concentrated under vacuum. The solid product of 11, which was for- 
R. M. Mohareb and H. Y. Hana: Synthesis of progesterone heterocyclic derivatives of potential antimicrobial activity, Acta Pharm. 58 (2008) 29-42.

med via the intermediate formation of the non isolable 10, was filtered off, dried and crystallized from ethanol.

Synthesis of 17-(pyrol-3-yl)androst-4-en-3-one (13)

To a solution of compound $2(0.66 \mathrm{~g}, 0.002 \mathrm{~mol})$ in acetic anhydride $(30 \mathrm{~mL})$, an equivalent amount of glycine $(0.15 \mathrm{~g}, 0.002 \mathrm{~mol})$ was added, the reaction mixture was heated under reflux for $3 \mathrm{~h}$, and then concentrated under vacuum. The solid product of 13, which was formed via the intermediate formation of the non isolable 12, was filtered off, dried and crystallized from ethanol.

Synthesis of 20-(cyanoacetylhydrazono)pregn-4-en-3-one (14)

A dry mixture of progesterone $1(1.57 \mathrm{~g}, 0.005 \mathrm{~mol})$ and freshly prepared cyanoacetic acid hydrazide $(0.49 \mathrm{~g}, 0.005 \mathrm{~mol})$ was heated in an oil bath at $130{ }^{\circ} \mathrm{C}$ for $1 \mathrm{~h}$ and then acetic acid $(5 \mathrm{~mL})$ was added. The solid product formed upon cooling at room temperature was triturated with ethanol, collected by filtration and crystallized from 1,4-dioxane.

Synthesis of 20-(1-phenyl-2-cyanopropenoylhydrazono)pregn-4-en-3-one (15)

To a solution of $14(0.79 \mathrm{~g}, 0.002 \mathrm{~mol})$ in absolute ethanol $(30 \mathrm{~mL})$ containing a catalytic amount of pyridine $(0.5 \mathrm{~mL})$, benzaldehyde $(0.21 \mathrm{~g}, 0.002 \mathrm{~mol})$ was added. The reaction mixture was heated under reflux for $4 \mathrm{~h}$ and then cooled at room temperature, poured over ice/water mixture and neutralized with dilute hydrochloric acid. The formed solid product was filtered off, dried and crystallized from methanol.

Synthesis of 20-hydrazono-N-(4-amino-3-cyano-2,6-dioxopyridin-1-yl)pregn-4-en-3-one (17)

To a solution of compound $14(0.79 \mathrm{~g}, 0.002 \mathrm{~mol})$ in ethanol containing a catalytic amount of pyridine $(0.5 \mathrm{~mL})$, an equivalent amount of ethyl cyanoacetate $(0.22 \mathrm{~g}, 0.002$ $\mathrm{mol}$ ) was added. The reaction mixture was heated under reflux for $4 \mathrm{~h}$, then left to cool at room temperature, poured over ice/water mixture and neutralized with dilute hydrochloric acid. The formed solid product of $\mathbf{1 7}$, which was formed via the intermediate formation of the non isolable 16, was filtered off, dried and crystallized from methanol.

Synthesis of 20-hydrazono-N-(4,6-dimethyl-2-oxopyridin-1-yl)pregn-4-en-3-one (18)

To a solution of $14(0.73 \mathrm{~g}, 0.002 \mathrm{~mol})$ in acetic anhydride $(30 \mathrm{~mL})$, an equivalent amount of acetyl acetone $(0.2 \mathrm{~g}, 0.002 \mathrm{~mol})$ was added. The reaction mixture was heated under reflux for $3 \mathrm{~h}$ and then concentrated under vacuum; the solid product so formed was filtered off, dried and crystallized from ethanol.

Synthesis of 20-(4-oxothiazol-2-acetylhydrazonyl-2-yl)pregn-4-en-3-one (19)

To a solution of compound $14(0.79 \mathrm{~g}, 0.002 \mathrm{~mol})$ in ethanol containing a catalytic amount of pyridine $(0.5 \mathrm{ml})$, an equivalent amount of thioglycolic acid $(0.18 \mathrm{~mL}, 0.002$ $\mathrm{mol}$ ) was added. The reaction mixture was heated under reflux for $5 \mathrm{~h}$ then left to cool at room temperature, poured over ice/water mixture and neutralized with dilute hydrochloric acid. The formed solid product was filtered off, dried and crystallized from ethanol. 
Synthesis of 20-(coumarin-3-carbohydrazonyl)pregn-4-en-3-one (20)

To a solution of $14(0.79 \mathrm{~g}, 0.002 \mathrm{~mol})$ in dimethylformamide $(30 \mathrm{~mL})$ containing a catalytic amount of piperidine $(0.5 \mathrm{~mL})$, salicylaldehyde $(0.002 \mathrm{~g}, 0.002 \mathrm{~mol})$ was added, the reaction mixture was heated under refluxal for $5 \mathrm{~h}$, cooled at room temperature, poured over ice/water mixture and neutralized with dilute hydrochloric acid. The formed solid product was filtered off, dried and crystallized from methanol.

Analytical and spectral data of all products are in agreement with the proposed structure.

\section{Antimicrobial activity}

The in vitro antimicrobial activity of the structurally promising steroidal heterocyclic derivatives $2,3 a, b, 6 b, 7,9,11,13,15,14,17,18$ and 20 against two strains of Gram positive bacteria (Bacillus subtilis CECT 498 and Bacillus cereus CECT 148), two strains of Gram negative bacteria (Escherichia coli ECT 101 and Pseudomonas aeruginosa) and Candida albicans CECT 1394 as a representative species of fungi was investigated. The newly synthesized products were dissolved in aqueous ethanol to give a logarithmic series of concentrations from 2 to $256 \mathrm{mg} \mathrm{L}^{-1}$ upon tenfold dilution with the growth medium and spore suspension of the test fungi. The toxicity of compounds was determined via pipette additions into the wells of multi-well slides, followed by $25 \mu \mathrm{L}$ of culture medium. The inoculated slides were then incubated at $25^{\circ} \mathrm{C}$ until short germ tubes appeared; approximately $50 \mu \mathrm{m}$ length (at $0 \mathrm{~h}$ ) was measured. Five- $\mu \mathrm{L}$ volumes of the prepared compound test solutions were added to the inoculated wells, one control well on each slide being treated with solvent only. The slides were then returned to the incubator until

Table III. Antimicrobial activities of tested compounds

\begin{tabular}{ccccc}
\hline \multirow{2}{*}{ Compd. } & \multicolumn{5}{c}{ MIC $\left(\mu \mathrm{g} \mathrm{mL}^{-1}\right)($ zone of inhibition, $\mathrm{mm})$} \\
\cline { 2 - 5 } & E. coli & B. cereus & B. subtilis & C. albicans \\
\hline $\mathbf{2}$ & $12.50(6)$ & $20.52(8)$ & $6.25(4)$ & $8.65(4)$ \\
$\mathbf{3 a}$ & - & $6.25(15)$ & $20.01(8)$ & $30.23(6)$ \\
$\mathbf{3 b}$ & - & $12.32(3)$ & $16.32(8)$ & $14.40(4)$ \\
$\mathbf{6 b}$ & - & $12.30(4)$ & $4.22(6)$ & $12.55(12)$ \\
$\mathbf{7}$ & - & $25.36(8)$ & $23.63(6)$ & $26.12(3)$ \\
$\mathbf{9}$ & - & $20.15(4)$ & $23.16(9)$ & $100.00(5)$ \\
$\mathbf{1 1}$ & 16.64 & $0.06(2)$ & $6.33(5)$ & $50.17(11)$ \\
$\mathbf{1 3}$ & - & $18.32(5)$ & $6.22(2)$ & $0.40(10)$ \\
$\mathbf{1 5}$ & $10.46(4)$ & $8.66(6)$ & $25.33(5)$ & $12.22(8)$ \\
$\mathbf{1 7}$ & - & $6.05(6)$ & $12.42(2)$ & $4.55(10)$ \\
$\mathbf{1 9}$ & - & $0.05(9)$ & $3.13(10)$ & $0.61(6)$ \\
$\mathbf{2 0}$ & - & $12.34(7)$ & $6.13(4)$ & $0.40(5)$ \\
Ampicillin & 6.25 & 3.13 & 12.50 & $(10)$ \\
- & - & - & & $12.50(6)$ \\
Cycloheximide & - & & & - \\
\hline
\end{tabular}


germ tubes $(400 \pm 50 \mu \mathrm{m})$ long were visible in the control wells. Further growth was arrested by the addition of lactophenol aniline blue to each of the wells. The minimal inhibitory concentration (MIC, in $\mu \mathrm{g} \mathrm{mL}^{-1}$ ) was determined using an adaptation of the agar streak dilution method based on radial diffusion $(9,10)$. Under the same conditions, ampicillin (antibacterial) and cycloheximide (antifungal) were used as standards. MIC was considered to be the lowest concentration of the tested compound (in dimethylformamide) that inhibits the growth of bacteria or fungi in the plate (Table III). Diameters of the inhibition zones corresponding to MICs are also presented in Table III.

\section{RESULTS AND DISCUSSION}

In this work, the reaction of progesterone (1) with dimethyl formamide dimethylacetal was studied. The reaction took place in xylene to give the enamine derivative 2 (8) (Scheme 1).<smiles>CC(=O)[C@@H]1CCC2C3CCC4=CC(=O)CC[C@]4(C)[C@H]3CC[C@]21C</smiles>

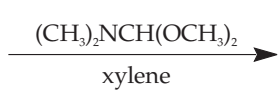

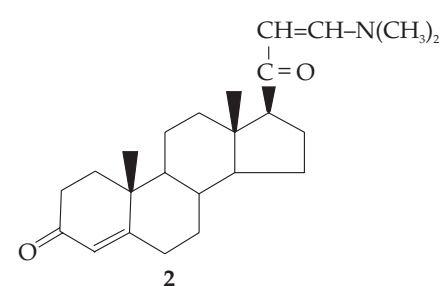

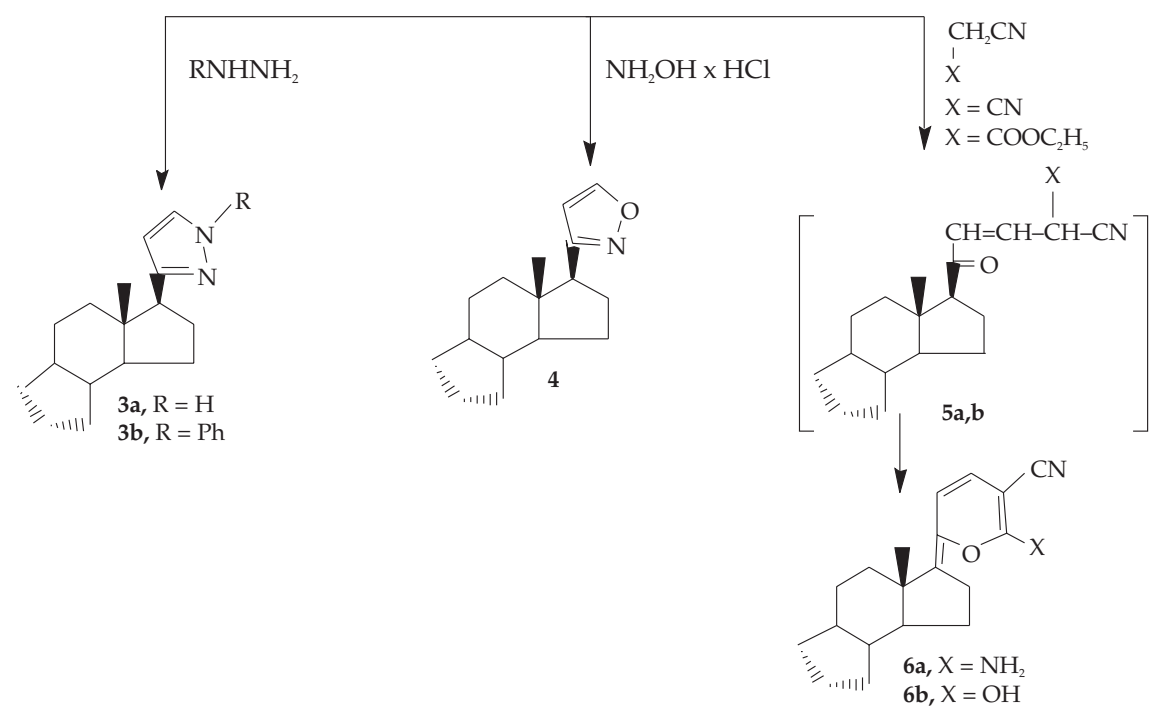

Scheme 1 
The heterocyclization of compound 2 with different chemical reagents was studied with the aim of forming steroidal heterocyclic compounds with potential biological activities. Thus, compound 2 reacted with either hydrazine hydrate or phenylhydrazine to give the pyrazolylandrostenone derivatives $3 a$ and $3 \mathbf{b}$, respectively, and the reaction of compound 2 with hydroxylamine hydrochloride gave the isoxazolyandrostenone derivative 4. The ${ }^{1} \mathrm{H}$ NMR of the latter product showed the presence of two doublets at $\delta 4.83$ and $5.23 \mathrm{ppm}$ for the isoxazole protons at C-4 and C-5, respectively. The reaction of compound 3 with either malononitrile or ethyl cyanoacetate gave the corresponding amino pyranylandrostenone derivatives $\mathbf{6} \mathbf{a}, \mathbf{b}$. Formation of the latter product took place through the intermediate formation of $\mathbf{5} \mathbf{a}, \mathbf{b}$ (Scheme 1 ).

The reaction of compound 2 with ethyl acetoacetate in acetic acid afforded the Knoevenagel condensation product 7 . On the other hand, carrying the same reaction in refluxing toluene gave the 3-acetyl-2-hydroxy pyranylandrostenone derivative 9 . The reaction took place through the intermediate formation of $\mathbf{8}$ (Scheme 2). The reaction of compound 2 with cyanoacetylhydrazone in 1,4-dioxane gave pyridazinylandrostenone

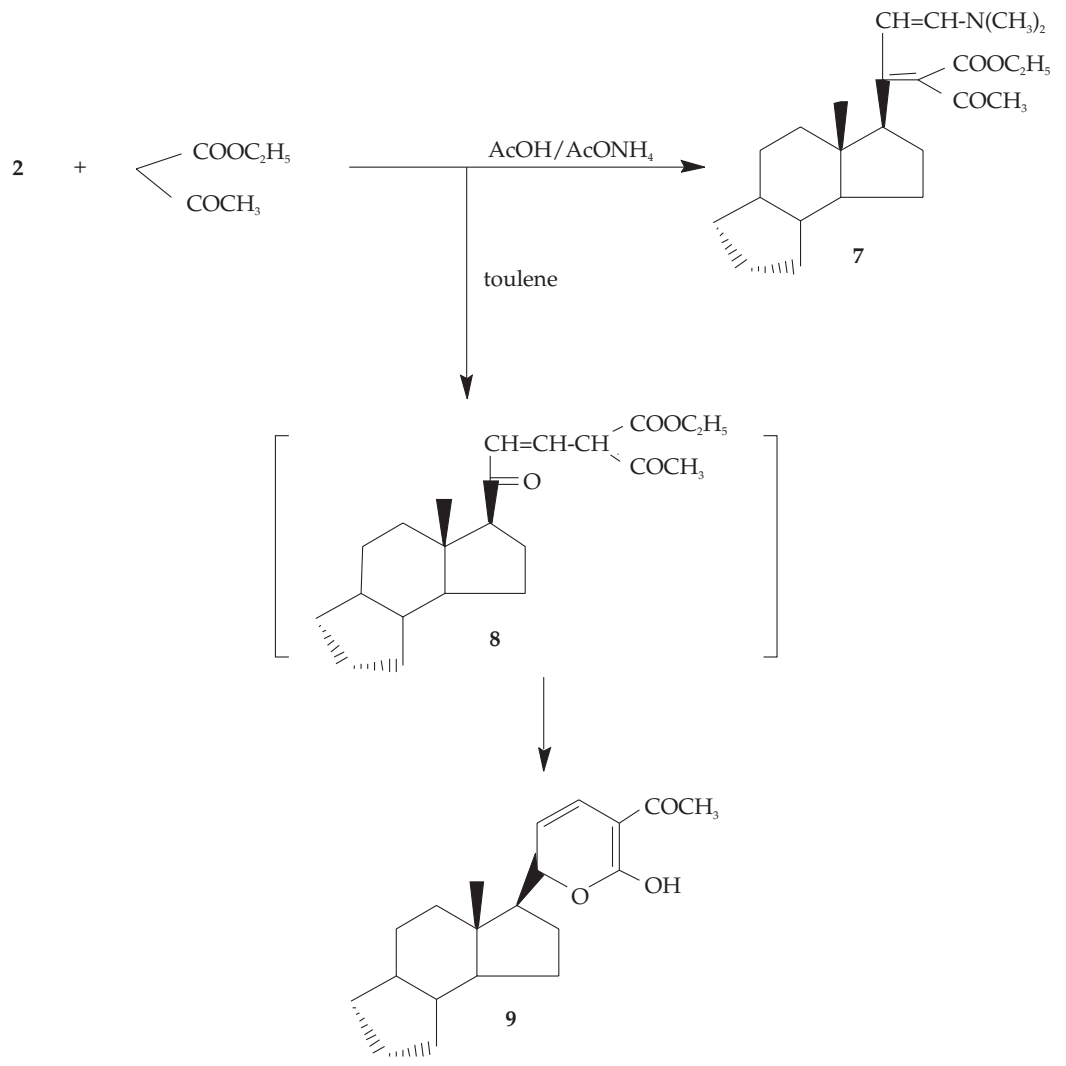

Scheme 2 
derivative $\mathbf{1 1}$ via the intermediate formation of $\mathbf{1 0}$ (Scheme 3). Thus, IR spectrum of compound 11 showed the presence of one $\mathrm{CN}$ group streching at $v 2225 \mathrm{~cm}^{-1}$. Moreover, the ${ }^{1} \mathrm{H}$ NMR spectrum showed the presence of two singlets at $\delta 0.78$ and $0.95 \mathrm{ppm}$ corresponding to two $\mathrm{CH}_{3}$ groups, a singlet at $\delta 2.11$ ppm for the $\mathrm{CH}_{2}$ group, a singlet at $\delta 4.70$ ppm for $\mathrm{C} 4-\mathrm{H}$ and two doublets at $\delta 5.93$ and 6.03 ppm corresponding to the pyridazine $\mathrm{H}-4$ and $\mathrm{H}-5$.

Compound 2 showed interesting reactivity when reacting with amino acids. Thus, with glycine in acetic anhydride it gave the pyrolylandrostenone derivative 13. Formation of $\mathbf{1 3}$ can be explained in terms of the first condensation of the glycine $\mathrm{CH}_{2}$ group with $\mathrm{C}=\mathrm{O}$ group at $\mathrm{C}-20$ of compound $\mathbf{2}$ to afford the intermediate $\mathbf{1 2}$ followed by cyclization and decarboxylation (Scheme 3). The analytical and spectral data of compound $\mathbf{1 3}$ are in agreement with the proposed structure (Tables I and II). Thus, the IR spectrum of compound 13 showed an NH stretching at $v 3334 \mathrm{~cm}^{-1}$. Moreover, the ${ }^{1} \mathrm{H}$ NMR spectrum revealed the presence of two singlets at $\delta 0.75$ and $0.92 \mathrm{ppm}$ corresponding to the two $\mathrm{CH}_{3}$ groups at $\mathrm{C}-18, \mathrm{C} 19$, a singlet at $\delta 4.97 \mathrm{ppm}$ for pyrazol $\mathrm{H}-4$, a multiplet at $\delta$ 5.23 ppm for pyrol H-2, H-3 and a siglet at $\delta 9.11$ ppmcorresponding to the NH group.

The reaction of progesterone (1) with cyanoacetic acid hydrazide, in refluxing 1,4-dioxane gave the cyanoacetylhydrazonopregnene derivative 14 . The condensation of $\mathrm{C}=\mathrm{O}$ group of progesterone (1) with the hydrazide to give hydrazone proceeds in parallel with another reaction recently reported by our group (11) (Scheme 4). The IR spectrum of the latter product showed a CN stretching at $v 2225 \mathrm{~cm}^{-1}$ and two $\mathrm{C}=\mathrm{O}$ groups stretching at $v 1718$ and $1715 \mathrm{~cm}^{-1}$. Moreover, the ${ }^{1} \mathrm{H}$ NMR showed the presence of a singlet at $\delta 2.11 \mathrm{ppm}$ for the $\mathrm{CH}_{2}$ group $\left(\mathrm{D}_{2} \mathrm{O}\right.$-exchangeable), a singlet at $\delta 9.55 \mathrm{ppm}$ for a NH group. The MS spectrum of $\mathbf{1 4}$ showed $\mathrm{m} / \mathrm{z}=395\left(\mathrm{M}^{+}\right)$.

Compound 14 reacted with benzaldehyde to give the benzal derivative 15 . The reaction of 14 with ethyl cyanoacetate gave 17. Formation of the latter product took place via the intermediate formation of $\mathbf{1 6}$. On the other hand, compound $\mathbf{1 4}$ reacted with acetyl-

2<smiles>C1CCCCCC1</smiles>
$\mathrm{CN}$

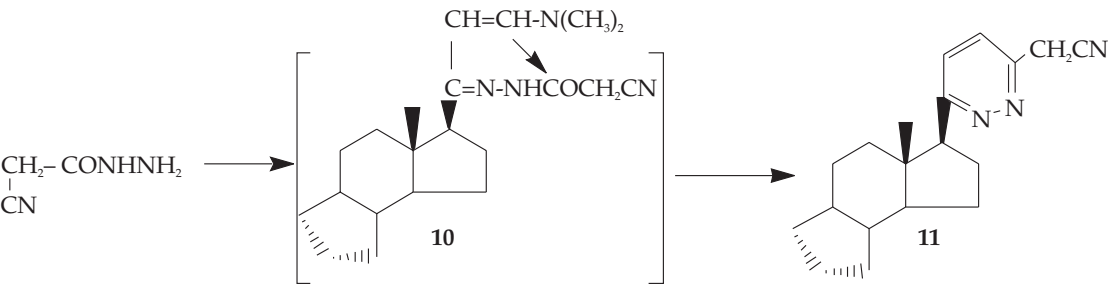

2<smiles>CCC(=O)O</smiles>
$\mathrm{NH}_{2}$

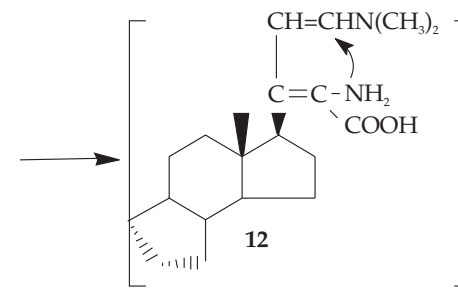

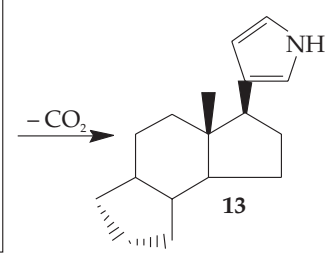

Shema 3 


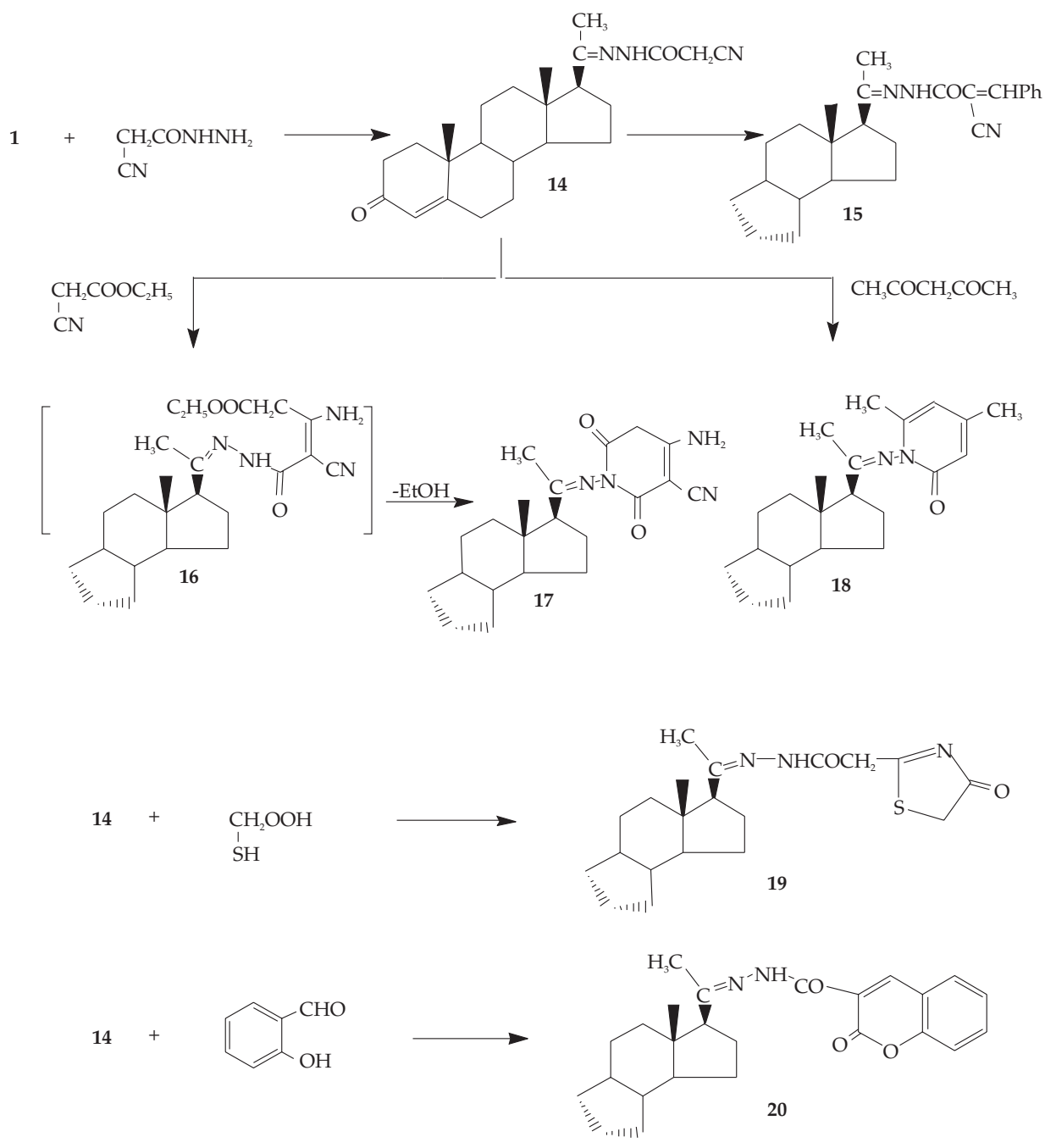

Shema 4

acetone to give the oxopyridinyl pregnene derivative 18 (Scheme 4). The reaction of compound 14 with thioglycolic acid gave the thiazolyl pregnene derivative 19 (12). The structure of the latter compound was based on analytical and spectral data (Tables I and II). Thus, the IR spectrum showed an NH stretching at $v 3325 \mathrm{~cm}^{-1}$ beside three $\mathrm{C}=\mathrm{O}$ groups stretching at $v 1718,1710$ and $1695 \mathrm{~cm}^{-1}$ and the ${ }^{1} \mathrm{H}$ NMR spectrum of 19 which showed two singlets at $\delta 0.78,0.95 \mathrm{ppm}$ for the two $\mathrm{CH}_{3}$ groups, a singlet at $\delta 4.93$ for the $\mathrm{CH}_{2}$, a singlet at $\delta 5.72 \mathrm{ppm}$ for the thiophene $\mathrm{H}-2$ and a singlet at $\delta 8.25$ ppm corresponding to the NH group. The MS spectrum of 19 showed $m / z=469\left(\mathrm{M}^{+}\right)$. On the other 
hand, the reaction of $\mathbf{1 4}$ with salicylaldehyde gave the coumarin derivative $\mathbf{2 0}$ (Scheme 4). Formation of coumarin via the reaction of salicylaldehyde with cyanomethylene reagents has been reported in literature $(13,14)$ where the condensation of salicylaldehyde with the active methylelene of the cyanomethylene reagent to form the corresponding non isolable arylidene was followed by cyclization and ammonia liberation to give the isolable coumarin product.

From Table III, it is obvious that no compound showed activity against Pseudomonas aeruginosa starting from DMSO solutions of $1000 \mu \mathrm{g} \mathrm{mL}-1$ of each compound. Compounds 2 (dimethylaminoacryloyl pregnenone), 11 [(17-(3-cyanomethylpyridazin-6-yl)androst-4-en-3-one] and 15 [20-(1-phenyl-2-cyanopropenoylhydrazono)pregn-4-en-3-one] were active against Escherichia coli only. The results in Table III also clearly revealed that all tested compounds in the present study, except for compounds 11 and 19 [20-(4oxothiazol-2-acetylhydrazonyl-2-yl)pregn-4-en-3-one], were active against Gram positive bacteria. However, compound 19 showed the least activity of the tested compounds. Compounds 2, 11, 15 are even more potent than the reference drug, ampicillin. Also, compounds 2, 3a [17-(pyrazol-3-yl)androst-4-en-3-one], $3 b$ [17-(1-phenylpyrazol-3-yl)androst-4-en-3-one], 6b [17-(2-hydroxy-3-cyanopyran-6-yl)androst-4-en-3-one], 7 [21(dimethylaminoacryloyl)-20-(ethylacetoacetato)pregn-4-en-3-one], 9, $\mathbf{1 1}$ and $\mathbf{1 5}$ are the most active compound against Candida albicans. Pyranylandrostenone derivative $\mathbf{9} \mathbf{6 b}$ [17-(2-hydroxy-3-acetylpyran-6-yl)androst-4-en-3-one] showed the maximum activity against $C$. albicans. Compounds 7 (with acetyl and ethyl ester groups) and $\mathbf{1 5}$ showed activity against $C$. albicans very close to that of the reference cycloheximide and higher than compounds 19 and 20 [20-(coumarin-3-carbohydrazonyl)pregn-4-en-3-one]. Compounds $2,6 b, 11,13,19$ and 20 showed lower activity against $B$. subtilis than the reference ampicillin. One can notice the difference between the structures of compounds 2 and 7; condensing the $\mathrm{C}=\mathrm{O}$ group in $\mathbf{2}$ with the acetyl and ethyl ester methino groups to produce compound 7 increases the activity of 7 against Candida albicans. The coumarin derivative 20 showed higher activity towards E. coli than the thiazole derivative 19.

\section{CONCLUSIONS}

The structure activity relationship suggested that heterocyclization reactions for enamine derivative of progesterone into pyrazole, isoxazole, pyrol, thiazole and coumarin derivatives resulted in products with high antibacterial and antifungal activity. These findings encourage us to explore new molecules by introducing potent moieties, like heterocyclic ring systems described in this work, into other hormones. Our prediction is that these compounds with new ring systems may show even better antimicrobial activity.

Acknowledgements. - R. M. Mohareb would like to thank the Alexander von Humboldt Foundation for affording a fellow ship in Germany during Summer 2006 and for completing the analytical data and antimicrobial tests in this work. 
R. M. Mohareb and H. Y. Hana: Synthesis of progesterone heterocyclic derivatives of potential antimicrobial activity, Acta Pharm. 58 (2008) 29-42.

\section{REFERENCES}

1. F. Desarnaud, A. N. Dothi, A. M. Brown, G. Lemke, U. Suter, E. E. Baulieu and M. Schumacher, Progesterone stimulates the activity of the promoters of peripheral myelin protein-22 and protein zero genes in Schwann cells, J. Neurochem. 71 (1998) 1765-1768.

2. R. C. Melcangi, V. Magnaghi, I. Cavarretta, I. Zucchi, P. Bovolin, D. D’Urso and L. Martini, Progesterone derivatives are able to influence peripheral myelin protein-22 and P0 gene expression: possible mechanisms of action, J. Neurosci. Res. 56 (1999) 349-357; DOI: 10.1002/(SICI)10974547(19990515).

3. R. M. Mohareb, J. Z. Ho and F. E. Elfarouk, Synthesis of thiophenes, azoles and azines with potential biological activity by employing the versatile heterocyclic precursor $N$-benzoylcyanoacetylhydrazine, J. Chin. Chem. Soc. 54 (2007) 1053-1066.

4. H. Z. Shams, R. M. Mohareb, M. H. Helal and A. E. Mahmoud, Synthesis, structure elucidation, and biological evaluation of some fused and/or pendant thiophene, pyrazole, imidazole, thiazole, triazole, triazine and coumarin systems based on cyanoacetic 2-[(benzoylamino)thioxomethyl]hydrazide, Phosphorus Sulfur 182 (2007) 237-263; DOI: 10.1080/1042500600892776.

5. R. M. Mohareb, J. Z. Ho and A. A. Mohamed, Uses of 1-cyanoacetyl-4-phenyl-3-thiosemicarbazide in heterocyclic synthesis: Synthesis of thiazole, coumarin and pyridine derivatives with antimicrobial and antifungal activities, Phosophus Sulfur 182 (2007) 1661-1681; DOI: 10.1080/ 10426500701289914.

6. IUPAC, Joint Commission on Biochemical Nomenclature (JCBN), Nomenclature of Steroids, Pure Appl. Chem. 61 (1989) 1783-1822.

7. IUPAC, Joint Commission on Biochemical Nomenclature (JCBN), The Nomenclature of Steroids, Recommendations (1989), Eur. J. Biochem. 186 (1989) 429-458.

8. O. Abdelhamid, M. M. Abdelhalim and G. A. Elmegeed, New routes to steroidal heterocyclic derivatives: synthesis of biologically active pyrazol- and isoxazolylpregnene derivatives, $\mathrm{J}$. $\mathrm{He}$ terocyclic Chem. 44 (2007) 7-11.

9. P. M. Hawkey and A. A. Lewis, Medical Bacteriology - A Practical Approach, Oxford University Press, Oxford 1994, pp. 181-194.

10. N. Rameshkumar, M. Ashokkumar, E. H. Subramanian, E. R. Ilavarasan and S. K. Sridhar, Synthesis of 6-flouro-1,4-dihydro-4-oxo-quinoline-3-carboxylic acid derivatives as potential antimicrobial agents, Eur. J. Med. Chem. 38 (2003) 1001-1004; DOI: 10.1016/S0223-5234(03)00151.

11. R. M. Mohareb, R. A. Ibrahim and J. Z. Ho, The reaction of cyanoacetylhydrazine with $\omega$-bromoacetophenone: Novel synthesis of 1,3,4-oxadiazine, pyridazine and coumarin derivatives, J. Chil. Chem. Soc. 52 (2007) 1076-1081.

12. Archana, V. K. Srivastava and A. Kumar, Synthesis of newer thiadiazolyl and thiazolidinonyl quinazolin-4(3H)-ones as potential anticonvulsant agents, Eur. J. Med. Chem. 37 (2002) 873-882; DOI: 10.1016/S0223-5234(02)01389-2.

13. D. I. Brahmbhatt, S. Shashibala and K. C. Patel, Characterization and biological activity of some polycoumarin ethylenes, Eur. Polymer J. 35 (1999) 317-324; DOI: 101016/ Chodankar and S. Seshadri, Absorption-emission spectra studies of 3-hetarylcoumarin, Dyes S0014-3057(98)00127.

14. N. K. Chodankar and S. Seshadri, Absorption-emission spectra studies of 3-hetarylcoumarin, Dyes Pigments 6 (1984) 331-340. 
R. M. Mohareb and H. Y. Hana: Synthesis of progesterone heterocyclic derivatives of potential antimicrobial activity, Acta Pharm. 58 (2008) $29-42$

\title{
$S A \check{Z} E T A K$
}

\section{Sinteza heterocikličkih derivata progesterona s antimikrobnim djelovanjem}

\author{
RAFAT M. MOHAREB i HANAA Y. HANA
}

U radu je opisana sinteza steroidnih heterocikličkih spojeva i evaluacija njihovog antimikrobnog djelovanja. Sintetizirani spojevi sadrže pirazol, izoksazol, tiazol, piran, piridin, piridazin ili benzopiran na pregnenskoj jezgri. Progesteron (1) je prvo u reakciji s dimetil formamid dimetil acetalom dao enamin 2. Novi steroidni heterociklički derivati dobiveni su heterociklizacijom spoja 2 s hidrazinima, hidroksilaminom, glicinom, etilacetoaceatom i cijanometilenom. Antimikrobno vrednovanje in vitro pokazalo je da su svi sintetizirani spojevi aktivni protiv testiranih Gram pozitivnih bakterija i gljivica.

Ključne riječi: progesteron, enamin, pirazol, piran, antimikrobno sredstvo

Department of Organic Chemistry, Faculty of Pharmacy, University of Modern Sciences and Arts (MSA), October City, Giza, Egypt

Hormone Department, National Research Centre, Dokki, Giza, Egypt 